\title{
Comparison of hemagglutinating, receptor-destroying, and acetylesterase activities of avirulent and virulent bovine coronavirus strains
}

\author{
J. Storz ${ }^{1}$, X. M. Zhang ${ }^{1}$, and R. Rott ${ }^{2}$ \\ ${ }^{1}$ Department of Veterinary Microbiology and Parasitology, School of Veterinary Medicine, \\ Louisiana State University, Baton Rouge, Louisiana, U.S.A. \\ ${ }^{2}$ Institut für Virologie, Justus-Liebig Universität, Giessen, Federal Republic of Germany
}

Accepted November 29, 1991

Summary. Hemagglutinating and acetylesterase functions as well as the $124 \mathrm{kDa}$ glycoprotein were present in the highly cell-culture adapted, avirulent bovine coronavirus strain BCV-L9, in the Norden vaccine strain derived from it, and in 5 wild-type, virulent strains that multiplied in HRT-18 cells but were restricted in several types of cultured bovine cells. The BCV-L9 and the wild-type strain BCV-LY-138 agglutinated chicken and mouse erythrocytes. The acetylesterase facilitated break-down of the BCV-erythrocyte complex with chicken but only to a minimal extent with mouse erythrocytes in the receptor-destroying enzyme test. Purified preparations of the vaccine and the wild-type strains agglutinated chicken erythrocytes at low titers and mouse erythrocytes at 128 to 256 times higher titers whereas receptor destroying enzyme activity was detectable only with chicken erythrocytes. When wild-type strains were propagated in HRT cells at low passage levels, they produced $5 \times 10^{5}$ to $4.5 \times 10^{6}$ plaque forming units per $50 \mu \mathrm{l}$ which agglutinated erythrocytes from mice but not from chickens. Diisopropylfluoro-phosphate moderately increased the hemagglutination titers, but completely inhibited the receptor destroying enzyme of purified virus of all strains. It had virtually no influence on the plaque-forming infectivity of the different BCV strains. The acetylesterase of strain BCV-L9 reacting in the receptor-destroying enzyme test was stable for $3 \mathrm{~h}$ at 37 and $42^{\circ} \mathrm{C}$. It was inactivated within $30 \mathrm{~min}$ at $56^{\circ} \mathrm{C}$ while the hemagglutinin function of this strain was stable for $3 \mathrm{~h}$ at 37,42 , and $56^{\circ} \mathrm{C}$, but it was inactivated at $65^{\circ} \mathrm{C}$ within $1 \mathrm{~h}$.

\section{Introduction}

Bovine coronavirus (BCV) has a hemagglutinin (HA) for some erythrocytes with an approximate molecular mass of $62 \mathrm{kDa}$ and $124 \mathrm{kDa}$ in the reduced 
and the nonreduced forms. This structural protein composes the short spikes of the viral envelope $[4,9,11]$. Acetylesterase activity (AE) was found associated with this glycoprotein of a BCV strain isolated from calves in the Netherlands and of the strain BCV-L9 $[15,16,28]$. This glycoprotein is now referred to as the hemagglutinin-esterase (HE) of $\mathrm{BCV}$ [2]. The AE inactivates the receptors for $\mathrm{BCV}$ of susceptible cells by hydrolyzing an ester bond to liberate acetate from C-9 of sialic acid $[15,16,29]$, an enzyme function first detected in the influenza $C$ virus by Herrler and coworkers [5]. The gene of the HE glycoprotein of $\mathrm{BCV}$ is located upstream of the $\mathrm{S}$ gene and predicts a protein with 424 amino acids $[7,12,33]$.

As an enteropathogen BCV causes severe diarrhea in neonatal calves, and it is also considered to be etiologically involved with winter dysentery of adult cattle $[4,11,14]$. BCV represents one of the better characterized coronaviruses with HA properties. Four major structural proteins are associated with infectious BCV. The $\mathrm{HE}$ as well as the spike or S glycoprotein $(190 \mathrm{kDa})$ and the integral membrane glycoprotein $\mathrm{M}(23-26 \mathrm{kDa})$ are associated with the viral envelope while the phosphorylated $\mathrm{N}$ protein $(50-54 \mathrm{kDa})$ functions as a nucleocapsid $[3,8,20,23]$. Proteolytic cleavage of the $\mathrm{S}$ glycoprotein precursor into $S 1$ and $S 2$ of 100 and $110 \mathrm{kDa}$ is required for cell fusion activity $[20,22]$. The S1/S2 glycoproteins facilitate virus attachment to susceptible cells, and also binding to erythrocytes, cell fusion, and induction of neutralizing antibodies $[17,20,22,24,25]$. The exact functions of $\mathrm{HE}$ and $\mathrm{S} 1 / \mathrm{S} 2$ and their interplay in the infectious process in vitro and in vivo are not fully defined $[17,24]$.

The presence and function of the $\mathrm{HE}$ was analyzed in two cell-adapted BCV strains $[15,24,28,29]$. Some of the $\mathrm{BCV}$ isolates from winter dysentery agglutinated rodent erythrocytes and others did not [1]. The objective of our investigations was to identify the $\mathrm{HE}$ of wild-type $\mathrm{BCV}$ strains at low passage levels in HRT cell cultures and to compare it with the HE of prototype BCVL9 and vaccine strains by relating its functions to the interaction with different erythrocytes, the effects of enzyme inhibitors, and to plaque-forming infectivity.

\section{Materials and methods}

\section{Bovine coronavirus isolates, their propagation, quantitation and purification}

The cell culture-adapted prototype BCV-L9 was originally isolated in bovine fetal kidney (BFK) cells from diarrhea fluid of a calf $[11,18]$. Our virus strain had been passaged 42 times in BFK cells, 16 times in bovine fetal brain cells, 15 times in bovine fetal spleen (BFS) cells, and 5 to 10 times in human rectal tumor (HRT-18) cells [20-22]. Five other wildtype BCV isolates, initially maintained by calf inoculation, were adapted to HRT-18 cells from diarrhea fluid or intestinal mucosal scrapings of calves with clinical diarrhea and electron microscopic evidence of coronavirus infection $[4,21]$. These strains are: BCVLY-138, BCV-C-50, BCV-Miller, BCV-Meeker, and BCV-Fisher. The vaccine strain of BCV was cultured in HRT-18 cells from the vaccine of Norden Laboratories, Omaha, Nebraska $[11,18]$. Importantly, cultivation of the BCV wild-type strains remained impossible for us until it was demonstrated that the cytopathic expression of BCV-L9 in cultured bovine cells was enhanced by trypsin [22] and that HRT-18 cells were susceptible 
to BCV [10]. These wild-type strains were completely restricted in a variety of cultured bovine cells even in the presence of trypsin [21].

The HRT-18 cells were cultured with Dulbecco's modified Earle's medium (DMEM) with $5 \%$ bovine fetal calf serum which was omitted from cultures used for virus propagation. A plaque assay in HRT-18 cells overlaid with $3 \mathrm{ml}$ of $1.2 \%(\mathrm{w} / \mathrm{v})$ agarose in DMEM containing $4 \mu \mathrm{g} / \mathrm{ml}$ final trypsin concentration was used to measure infectivity $[22,27]$. Samples of the 7 BCV strains were propagated in HRT cells and purified as described [6, $20,30]$.

\section{$B C V-L 9$ infected cell lysate}

The BCV-L9-infected cell sediment of the first step in the virus purification was suspended in $7.5 \mathrm{ml}$ phosphate buffered saline (pH of 7.4), treated with sound 3 times for $15 \mathrm{~s}$ at a power setting of 4 (Branson Sonifyer), and centrifuged at $3000 \times \mathbf{g}$ for $30 \mathrm{~min}$. The supernatant fluid represented the BCV-L9-infected cell lysate. Uninfected HRT-18 cells were treated the same way and were used in control tests.

\section{Acetylesterase assay}

Acetylesterase activity of purified BCV preparations was determined according to Vlasak et al. [28]. Purified preparations of the different BCV strains were added in $5 \mu 1$ quantities to $1 \mathrm{ml}$ of phosphate buffered saline containing $1 \mathrm{mM}$ p-nitrophenylacetate (PNPA). The PNPA was initially dissolved in ethyl alcohol. Hydrolysis of the substrate was monitored at $405 \mathrm{~nm}$ in a Beckman spectrometer with multiple cuvette sets and a chart recorder. The reaction was measured at $1 \mathrm{~min}$ intervals for $5 \mathrm{~min}$. The $5 \mathrm{~min}$ value was used for comparisons $[15,16]$.

\section{Assays for hemagglutination ( $H A)$ and receptor-destroying enzyme ( $R D E$ )}

The HA test was employing $0.5 \%$ suspensions of erythrocytes from adult chickens or mice [5]. The tests with 2 -fold $\mathrm{BCV}$ dilutions in $50 \mu$ l quantities were initially incubated at $4^{\circ} \mathrm{C}$ for $1 \mathrm{~h}$ to assess the HA titers. Thereafter, the microtiter plates were shifted to $37^{\circ} \mathrm{C}$ for $1 \mathrm{~h}$ to monitor inactivation of receptors reflected by the breakdown of the $\mathrm{BCV}$-erythrocyte complexes mediated by the $\mathrm{AE}$ in the RDE assay. The extent of disappearance of the BCVerythrocyte aggregates was recorded in a final evaluation made following an additional 4 to $6 \mathrm{~h}$ at room temperature when unequivocal interpretation of the results was possible [24].

\section{Inhibitors of $H A$ and $R D E$}

Diisopropylfluorophosphate (DFP) was used as an inhibitor of serine esterase activity to assess the effect of AE from different BCV strains on the HA and RDE functions as well as on BCV infectivity. A sample of $50 \mu 1$ of each purified BCV strain was treated with $1 \mathrm{mM}$ of DFP in $10 \mu \mathrm{l}$ for $10 \mathrm{~min}$ at room temperature. The virus samples were then diluted in 2 fold steps and tested for HA and RDE activities. Untreated samples were tested in parallel. Similarly, $10 \mu \mathrm{l}$ aliquots of the purified BCV strains were treated with $1 \mathrm{mM}$ of DFP in $10 \mu \mathrm{l}$ for $10 \mathrm{~min}$ at room temperature. Samples were then mixed with $980 \mu 1$ of PBS, and further decimal dilutions were made. The infectivity of DFP-treated and untreated $\mathrm{BCV}$ preparations was assayed in the plaque test [22]. Bovine submaxillary mucin (BSM) was tested with 2-fold dilutions of the purified virus preparations by adding $50 \mu l$ of the $1 \mathrm{mg} / \mathrm{ml}$ BSM. Alternatively, the indicated inhibitor concentrations was diluted 2 -fold and $8 \mathrm{HA}$ units of the strains BCV-L9 or BCV-LY-138 were added. Chicken erythrocytes as well as mouse erythrocytes were employed in these tests. 


\section{Thermal inactivation of $H A$ and $R D E$}

Aliquots of the BCV-L9-infected cell lysate having HA and RDE titers of 128 with chicken erythrocytes were incubated at $37^{\circ} \mathrm{C}, 42^{\circ} \mathrm{C}, 56^{\circ} \mathrm{C}$ and $65^{\circ} \mathrm{C}$. Samples were withdrawn at intervals of $10 \mathrm{~min}$ for $1 \mathrm{~h}$ and every $30 \mathrm{~min}$ for the next $2 \mathrm{~h}$ to be tested for HA and RDE activities.

\section{Detection of the $124 \mathrm{kDa}$ glycoprotein}

Sodium dodesyl sulfate-polyacrylamide gel electrophoresis (SDS-PAGE) was performed in $12 \%$ slab gels under denaturing and under mildly denaturing conditions. Detailed procedures for the analysis of BCV proteins by SDS-PAGE were described [6, 20].

\section{Results}

Infectivity and detection of $A E, H A$, and $R D E$ activities of purified virus preparations from different $B C V$ strains

The different viral functions were assessed on purified BCV samples containing infectivities of $2.5 \times 10^{6}$ to $1.2 \times 10^{8}$ PFUs per $50 \mu$ l (Table 1). AE activity was detected in the PNPA test and the gp $124 \mathrm{HE}$ structural protein was seen in PAGE of all BCV strains tested. The highest AE activity was detected in the BCV-LY-138 strain and this strain had also the highest infectivity even though it was only in the 5th passage in HRT-18 cells. Purified virus preparations of the strains BCV-L9 and BCV-LY-138 agglutinated chicken erythrocytes at titers of 1024 and 4096, respectively, but the HA titers were 8 and 4 fold higher with mouse erythrocytes. In contrast, the vaccine and three wild-type BCV strains had HA titers of 32 to 128 with chicken erythrocytes, and 128 to 256 fold higher titers were recorded with mouse erythrocytes. RDE activity was detected at titers of 16 to 64 with chicken erythrocytes whereby HA:RDE ratios of $1: 1$ were evident for the strains BCV-Meeker, BCV-Fisher and BCV-Calf-50. The RDE activity was minimal or not detectable in tests involving mouse erythrocytes. The PFUs per HA unit ranged from $2.6 \times 10^{4}$ to $1.5 \times 10^{6}$ for chicken erythrocytes and $3 \times 10^{2}$ to $7.3 \times 10^{3}$ for mouse erythrocytes (Table 1 ).

Infectivity and detection of $H A$ and $R D E$ functions released from $H R T$ cellcultures infected with different $B C V$ strains at high and low passage levels

The HA pattern of the highly cell-culture adapted and the wild-type BCV strains differed. The BCV-L9 strain was in the 78th cell culture passage while the wildtype strains had been passed only 3 to 7 times in HRT-18 cells. Strains BCVL9 and BCV-LY-138 agglutinated chicken erythrocytes while the other BCV strains did not (Table 2). All strains agglutinated mouse erythrocytes. The infectivity of the preparations ranged from $5 \times 10^{5}$ to $4.5 \times 10^{6}$ PFUs. RDE activity for receptors on chicken erythrocytes was detected in samples from BCV-L9 and BCV-LY-138. 


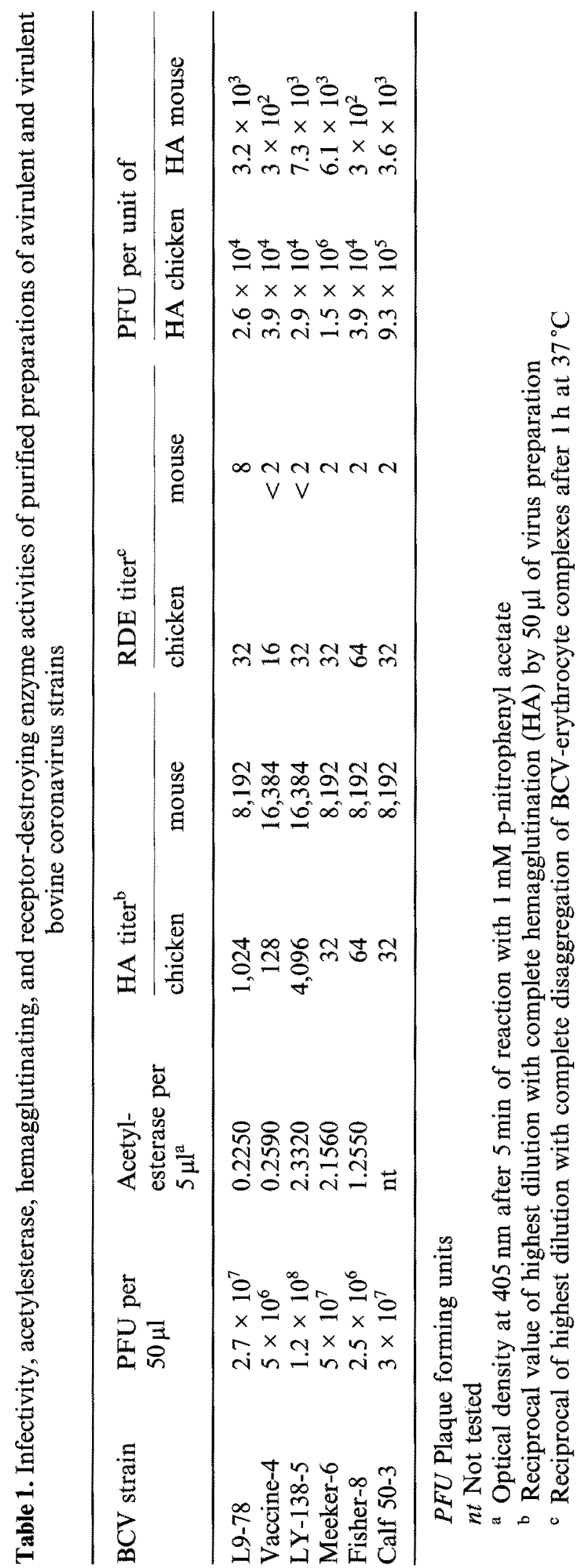


Table 2. Correlation between infectivity, hemagglutination and receptor-destroying enzyme activities of different BCV strains at various passage levels in HRT cells

\begin{tabular}{|c|c|c|c|c|c|}
\hline \multirow{2}{*}{$\begin{array}{l}\text { BCV strain and } \\
\text { HRT-passage level }\end{array}$} & \multirow[t]{2}{*}{$\mathrm{PFU} / 50 \mu \mathrm{I}$} & \multicolumn{2}{|c|}{ Chicken RBC } & \multicolumn{2}{|c|}{ Mouse RBC } \\
\hline & & $\mathrm{HA}^{\mathrm{b}}$ & $\mathrm{RDE}^{\mathrm{c}}$ & $\mathrm{HA}$ & $\mathrm{RDE}$ \\
\hline $\mathrm{L} 9-79^{\mathrm{a}}$ & $4.5 \times 10^{6}$ & 256 & 8 & 512 & $<2$ \\
\hline LY-138-5 & $1.5 \times 10^{6}$ & 128 & 8 & 32 & $<2$ \\
\hline Vaccine-3 & $5 \times 10^{5}$ & $<2$ & $<2$ & 32 & $<2$ \\
\hline Meeker-7 & $7 \times 10^{6}$ & $<2$ & $<2$ & 64 & $<2$ \\
\hline Fisher-6 & $3.5 \times 10^{6}$ & $<2$ & $<2$ & 64 & $<2$ \\
\hline Calf $50-3$ & $5 \times 10^{5}$ & $<2$ & $<2$ & 64 & $<2$ \\
\hline Miller-6 & $1.5 \times 10^{6}$ & $<2$ & $<2$ & 64 & $<2$ \\
\hline
\end{tabular}

a 5 passages in HRT and numerous passages in cultured bovine cells

b Reciprocal value of highest dilution with complete hemagglutination by $50 \mu \mathrm{l}$ of virus preparation

${ }^{c}$ Reciprocal of highest dilution with complete disaggregation of BCV-erythrocyte complexes after $1 \mathrm{~h}$ at $37^{\circ} \mathrm{C}$

Effect of inhibitors on infectivity, $H A$ and $R D E$ activities of purified virus preparations of different $B C V$ strains

The BCV infectivity was virtually unaffected by DFP (Table 3). In contrast, the RDE activity for chicken erythrocytes was completely inhibited. The HA titers for chicken erythrocytes were 2 to 64 times higher after DFP treatment. The RDE activity for mouse erythrocytes was eliminated by DFP and an enhancing effect on HA was not noticed. BSM inhibited HA by BCV-L9 and the vaccine strain, while it reduced the HA titers of the other strains for chicken erythrocytes (Table 4). Mouse erythrocytes became aggregated in the control tests by BSM at the concentration used.

\section{Thermal inactivation of $H A$ and $R D E$ activities of $B C V$-strain $B C V-L 9$}

The BCV-L9-infected cell lysate was used to assess thermal inactivation of the HA and RDE functions for chicken erythrocytes. As documented in Figs. 1 and 2 these activities remained unaffected at temperatures of $37^{\circ} \mathrm{C}$ and $42^{\circ} \mathrm{C}$ for $3 \mathrm{~h}$. The RDE titer was reduced from 256 to $<2$ within $30 \mathrm{~min}$ at $56^{\circ} \mathrm{C}$ while HA remained constant. This activity was lost within $60 \mathrm{~min}$ at $65^{\circ} \mathrm{C}$.

\section{Discussion}

All BCV strains tested had AE activities when purified preparations were assayed in the PNPA test [28]. This enzyme was inhibited by the serine esterase inhibitor DFP when assayed in the AE-mediated breakdown of BCV-chicken erythrocyte complexes yet the HA titers of purified preparations of wild-type BCV strains were increased 2 to 64 fold at $4^{\circ} \mathrm{C}$. The infectivity of identically DFP-treated 


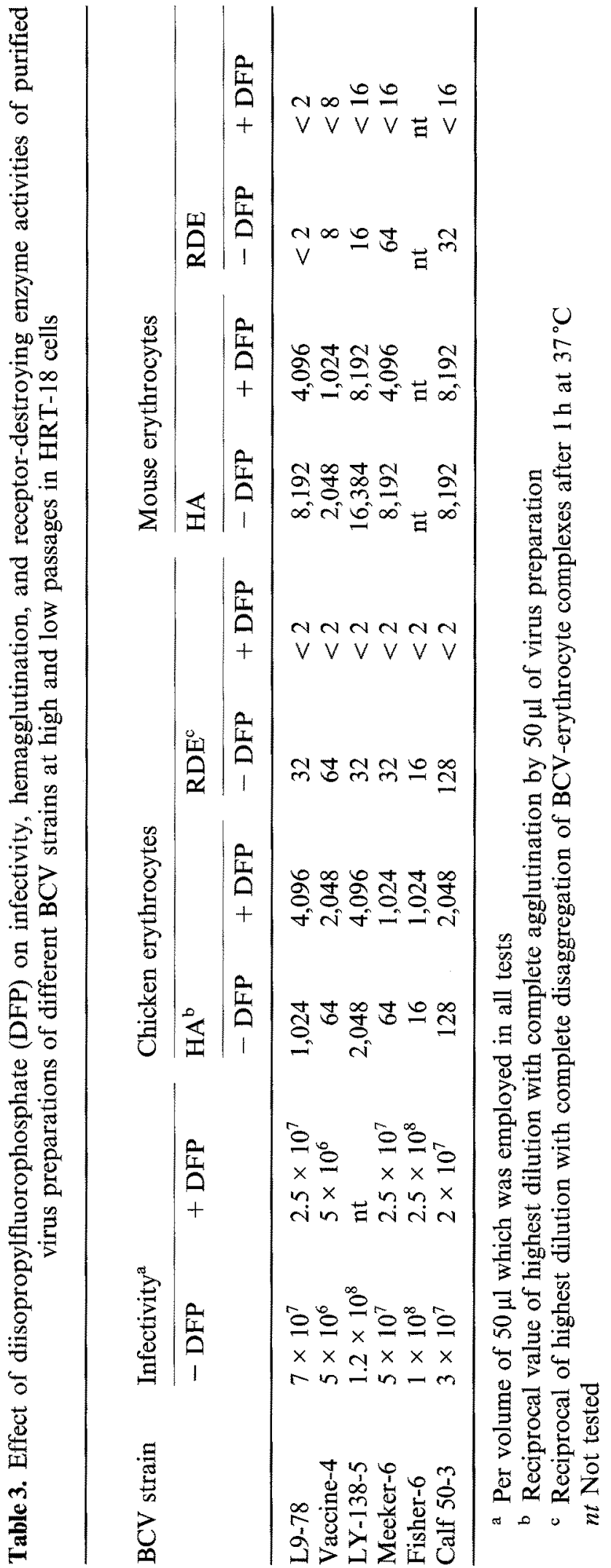


Table 4. Inhibition of hemagglutination and receptor-destroying enzyme functions of purified virus from different BCV strains by bovine submaxillary mucine (BSM)

\begin{tabular}{lccccc}
\hline BCV Strain & \multicolumn{2}{l}{ Hemagglutination $^{\mathrm{a}}$} & & \multicolumn{2}{l}{ Receptor-destroying enzyme $^{\mathrm{a}}$} \\
\cline { 2 - 3 } \cline { 5 - 6 } & control & + BSM $^{\mathrm{b}}$ & & control & + BSM \\
\hline L9-78 & 256 & $<2$ & 8 & $<2$ \\
Vaccine-4 & 16 & $<2$ & & 16 & $<2$ \\
LY-138-5 & 256 & 8 & 8 & 2 \\
Meeker-6 & 32 & 16 & & 32 & 8 \\
Fisher-8 & 64 & 8 & & 32 & 32 \\
Calf 50-5 & 32 & 32 & & 32 & 32 \\
\hline
\end{tabular}

${ }^{\text {a }}$ With chicken erythrocytes; mouse erythrocytes were agglutinated by BSM; the volume was $50 \mu \mathrm{l}$ for all components in these tests

b $1 \mathrm{mg} / \mathrm{ml}$

BCV samples was not significantly reduced when compared with the untreated samples in the plaque test employing HRT-18 cells (Table 1). These results indicate that the $\mathrm{AE}$ of the $\mathrm{BCV}$ is probably not directly involved in viral uptake during the infectious process. Receptor binding and viral attachment to susceptible cells in infections of non-HA and HA coronaviruses are mediated by the $\mathrm{S}$ glycoprotein [19]. The HE protein is not expressed in some murine coronavirus strains [31]. Our finding contrasts a previous report of a 100 -fold reduction of infectivity by DFP of another BCV strain plaque-assayed in MadinDarby bovine kidney cells [28]. Infectivity assayed by the plaque test does not address the potential significance of $\mathrm{AE}$ in viral spread within an infected cell culture or animal. The AE activity of the HE protein may play a role in facilitating virus release from infected cells and viral spread. BCV particles were seen adsorbed abundantly to the plasmalemma or microvilli. Adsorbed BCV covered the entire exposed surfaces of enterocytes in infections of calves [4] and HRT cells [13]. Further insight into the role of $\mathrm{HE}$ will be gained through investigations of the interactions of $\mathrm{HE}$ with cellular receptors in vitro as well as with the neuraminidate-containing glycokalyx protecting mucous membranes of the respiratory and intestinal tracts of hosts. The strongly inhibitory function of BSM on HA points in this direction (Table 4).

One difference between the BCV-L9 and BCV-LY-138 strains and the vaccine, Meeker, Fisher and Calf-50 strains involves their interaction with different erythrocytes. Chicken erythrocytes were agglutinated by BCV-L9 and BCVLY-138 and the RDE functioned. These strains also agglutinated mouse erythrocytes, but elution through $\mathrm{RDE}$ activity was minimal. The approximately 100 -fold concentrated purified preparations of the other BCV strains agglutinated chicken erythrocytes at low titers which were increased by DFP. The HA titers with mouse erythrocytes were 128 to 256 fold higher, but virtually no RDE function was detectable (Table 1). This difference was further substantiated 


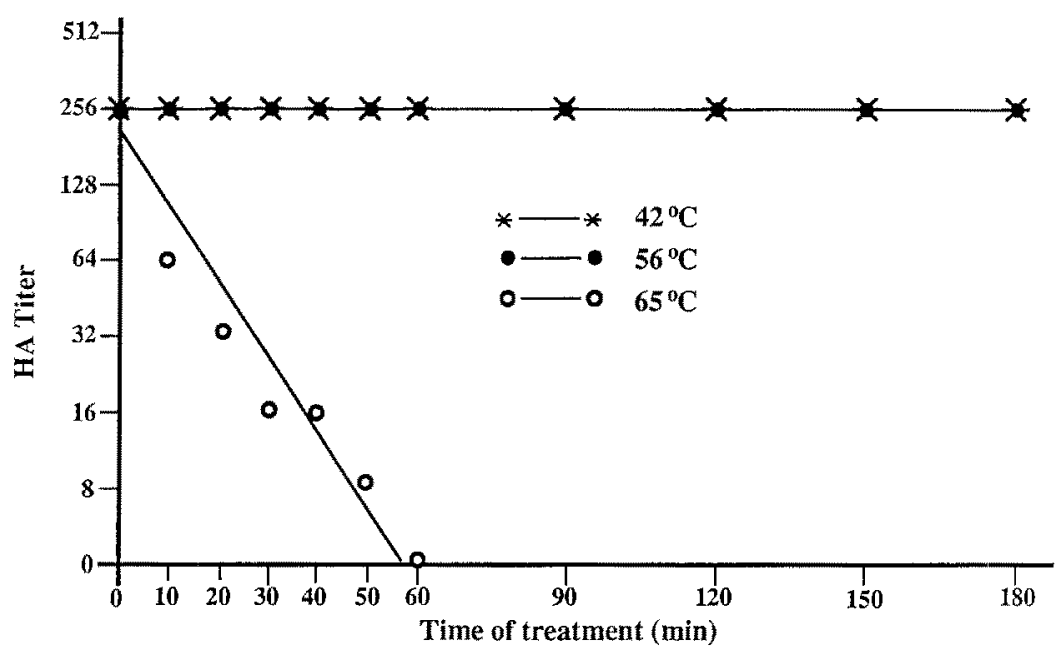

Fig. 1. Thermal inactivation of the hemagglutinating activity of BCV-L9

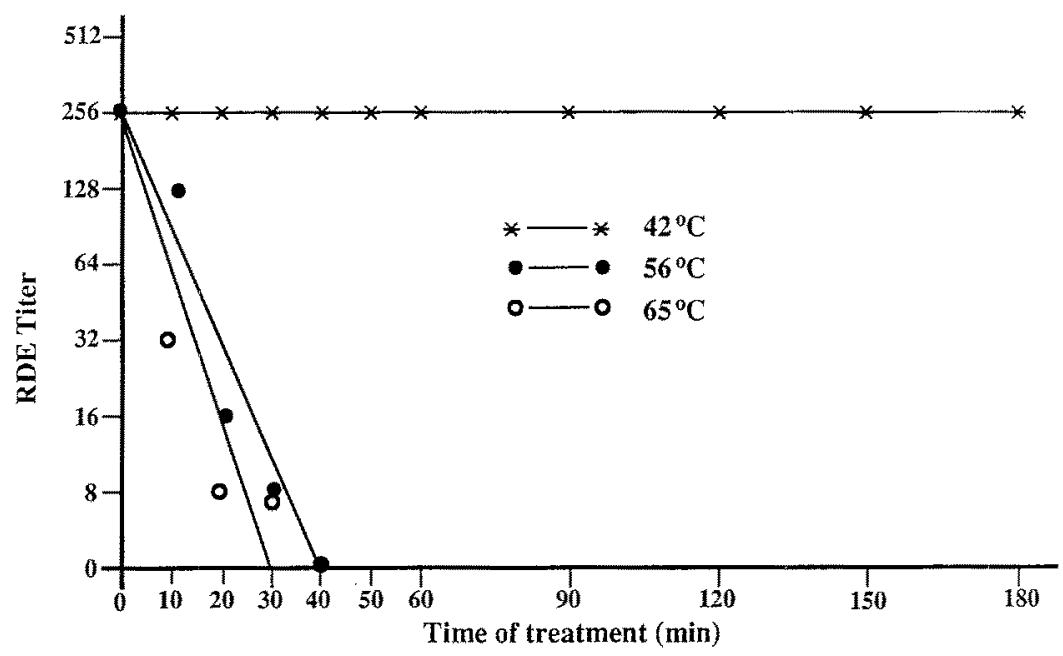

Fig. 2. Thermal inactivation of the receptor destroying activity mediated by the acetylesterase of BCV-L9

in HA tests with fluids from HRT-18 cell cultures infected with the different BCV strains at low passages. The vaccine, Meeker, Fisher, Calf 50 and Miller BCV strains agglutinated mouse but not chicken erythrocytes at infectivity yields of $5 \times 10^{5}$ to $4.5 \times 10^{6} \mathrm{PFU} \mathrm{s} / 50 \mu \mathrm{l}$ (Table 2). The difference in the HA pattern of the avirulent and virulent strains may be determined by straindependent receptor binding properties, or possible differences between $\mathrm{Neu} 5,9 \mathrm{Ac}_{2}$-containing receptors on chicken and mouse erythrocytes, or the greater abundance of receptors on mouse erythrocytes [17]. Further differences between the avirulent strain BCV L9 and the virulent strains are host cell restriction [21, 22], epitopes for S-specific monoclonal antibodies [6], and amino acid substitutions among the $\mathrm{S}$ and HE proteins [32, 33]. Adaptation 
of wild-type BCV strains to cell cultures and the associated viral selection clearly involve significant genetic and functional changes.

The difference in thermal sensitivity separated AE or RDE activity from the HA function. These studies do not define the structural proteins of BCV involved in $\mathrm{HA}$. Monoclonal antibodies against $\mathrm{HE}$ as well as against $\mathrm{S}$ inhibited HA by BCV-L9. The activity of anti HE monoclonal antibodies was predominately against RDE [24]. Purified HE of BCV-L9 had AE activity but agglutinated only mouse erythrocytes while purified $S$ was a more powerful HA for chicken and mouse erythrocytes [17]. The functions of $S$ and $H E$, and their interplay in receptor binding, $\mathrm{HA}$, and the infectious process of $\mathrm{BCV}$ need to be defined.

\section{Acknowledgements}

We thank Dr. Georg Herrler for enhancing discussions and help with the acetylesterase tests. The dedication and excellent technical assistance of Eva Kroell is greatly appreciated. These investigations were made possible through a sabbatical leave in the Institut für Virologie, Justus Liebig Universität, Giessen, granted to J. S. by Louisiana State University, a reinvitation grant by the Alexander von Humboldt Foundation, through research grants 86-CSRS-2-2871 and 89-34116-4675 from the United States Department of Agriculture, and a grant from the Louisiana Education Quality Support Fund.

\section{References}

1. Benfield DA, Saif LJ (1990) Cell culture propagation of a coronavirus isolated from cows with winter dysentery. J Clin Microbiol 28: 1454-1457

2. Cavanagh D, Brian DA, Enjuanes L, Holmes KV, Lai MC, Laude H, Siddell SG, Spaan W, Taguchi F, Talbot OJ (1990) Recommendations of the coronavirus study group for the nomenclature of the structural proteins, mRNAs, and genes of coronaviruses. Virology 176: 306-307

3. Deregt D, Sabara M, Babiuk LA (1987) Structural proteins of bovine coronavirus and their intracellular processing. J Gen Virol 68: 2863-2877

4. Doughri AM, Storz J, Hajer I, Fernando S (1976) Morphology and morphogenesis of a coronavirus infecting intestinal epithelial cells of newborn calves. Exp Mol Pathol 25: $355-370$

5. Herrler G, Rott R, Klenk HD, Müller HP, Shukda AK, Schauer R (1985) The receptordestroying enzyme of influenza $\mathrm{C}$ is virus neuraminidate-O-acetyl-esterase. EMBO J 4: $1503-1506$

6. Hussain KA, Storz J, Kousoulas KG (1991) Comparison of bovine coronavirus (BVC) antigens: monoclonal antibodies to glycoprotein GP 100 distinguish between vaccine and wild-type strains. Virology 183: 442-445

7. Kienzle TE, Abraham S, Hogue BG, Brian DA (1990) Structure and orientation of expressed bovine coronavirus hemagglutinin-esterase protein. J Virol 64: 1834-1838

8. King B, Brian DA (1982) Bovine coronavirus structural proteins. J Virol 42: 700-707

9. King B, Potts B, Brian DA (1985) Bovine coronavirus hemagglutinin protein. Virus Res 2: 53-59

10. Laporte J, L'Haridon R, Bobulesco P (1979) In vitro culture of bovine enteric coronavirus (BEC). INSERM 90: 99-102

11. Mebus CA, Stair EL, Rhodes MB, Twiehaus MJ (1973) Neonatal calf diarrhea: propagation, attenuation, and characteristics of coronavirus-like agents. Am J Vet Res 34: $145-150$ 
12. Parker MD, Cox GJ, Deregt D, Fitzpatrick DR, Babiuk LA (1989) Cloning and in vitro expression of the gene for the $\mathrm{E} 3$ hemagglutinin glycoprotein of bovine coronavirus. J Gen Virol 70: 155-164

13. Payne HR, Storz J (1990) Scanning electron microscopic characterization of bovine coronavirus plaques in HRT cells. J Vet Med B 37: 501-508

14. Saif LJ, Redman DR, Brock KV, Kohler EM, Heckert RA (1988) Winter dysentery in adult dairy cattle: detection of coronaviruses in the feces. Vet Rec 123: 300-301

15. Schultze B, Gross HJ, Brossmer R, Klenk HD, Herrler G (1990) Hemagglutinating encephalomyelitis virus attaches to $\mathrm{N}$-acetyl-9-0-acetylneuraminic acid-containing receptors on erythrocytes: comparison with bovine coronavirus and influenza $\mathrm{C}$ virus. Virus Res 16: 185-194

16. Schultze B, Wahn K, Klenk HD, Herrler G (1991) Isolated HE protein from hemagglutinating encephalomyelitis virus and bovine coronavirus has receptor-destroying and receptor-binding activity. Virology 180: 221-228

17. Schultze B, Gross HJ, Brossmer R, Herrler G(1991) The S protein of bovine coronavirus is a hemagglutinin recognizing $9-0$-acetylate sialic acid as a receptor determinant. $J$ Virol 65: 6232-6237

18. Sharpee RL, Mebus CA, Bass EP (1976) Characterization of a calf diarrheal coronavirus. Am J Vet Res 37: 1031-1041

19. Spaan W, Cavanagh D, Horzinek MC (1988) Coronaviruses: structure and genome expression. J Gen Virol 69: 2939-2952

20. St. Cyr-Coats K, Storz J, Hussain KA, Schnorr KL (1988) Structural proteins of bovine coronavirus strain L9: effects of the host cell and trypsin treatment. Arch Virol 103: $35-45$

21. St. Cyr-Coats K, Storz J (1988) Bovine coronavirus-induced cytopathic expression and plaque formation: host cell and virus strain determine trypsin dependence. $\mathrm{J}$ Vet Med B 35: $48-56$

22. Storz J, Rott R, Kaluza G (1981) Enhancement of plaque formation and cell fusion of an enteropathogenic coronavirus by trypsin treatment. Infect Immun 31: 1214-1222

23. Storz J, Kaluza G, Niemann H, Rott R (1983) On enteropathogenic bovine coronavirus. In: ter Meulen (ed) Proceedings of the international symposium on the biochemistry and biology of coronaviruses. Plenum, New York, pp 171-180

24. Storz J, Herrler G, Snodgrass DR, Hussain KA, Zhang XM, Clark MA, Rott R (1991) Monoclonal antibodies differentiate between the hemagglutinating and the receptordestroying activities of bovine coronavirus. J Gen Virol 72: 2817-2820

25. Sturman LS, Holmes KV (1983) The molecular biology of coronaviruses. Adv Virus Res 28: $35-112$

26. Sturman LS, Ricard CS, Holmes KV (1985) Proteolytic cleavage of the E 2 glycoprotein of murine coronavirus: activation of cell-fusing activity of virions by trypsin and separation of two different $90 \mathrm{k}$ cleavage fragments. J Virol 56: 904-911

27. Tompkins WAF, Watrach AM, Schmale JD, Schultz RM, Harris JA (1974) Cultural and antigenic properties of newly established cell strains derived from adenocarcinomas of the human colon and rectum. J Natl Cancer Inst 52: 904-911

28. Vlasak R, Luytjes W, Leider J, Spaan W, Palese P (1988) The E 3 protein of bovine coronavirus is a receptor-destroying enzyme with acetylesterase activity. $\mathrm{J}$ Virol 62 : 4686-4690

29. Vlasak R, Luytjes W, Spaan W, Palese P (1988) Human and bovine coronaviruses recognizes sialic acid-containing receptors similar to those of influenza $\mathrm{C}$ viruses. Proc Natl Acad Sci USA 85: 4526-4529

30. Wege H, Wege H, Nagashima K, ter Meulen V (1979) Structural polypeptides of the murine coronavirus JHM. J Gen Virol 42: 37-47

31. Yokomori K, LaMonica N, Makino S, Shieh CK, Lai MC (1989) Biosynthesis, struc- 
204 J. Storz et al.: Hemagglutinating and acetylesterase activities in BCV strains

ture, and biological activities of envelope protein gp 65 of murine coronavirus. Virology 173: $683-691$

32. Zhang XM, Kousoulas KG, Storz J (1991) Comparison of the nucleotide and deduced amino acid sequences of the $S$ genes specified by virulent and avirulent strains of bovine coronaviruses. Virology 183: 397-404

33. Zhang XM, Kousoulas KG, Storz J (1991) The hemagglutinin/esterase glycoproteins of bovine coronaviruses: sequence and functional comparisons between virulent and avirulent strains. Virology 185: 847-852

Authors' address: Dr. J. Storz, Department of Veterinary Microbiology and Parasitology, School of Veterinary Medicine, Louisiana State University, Baton Rouge, LA 70803, U.S.A.

Received August 8, 1991 